Syntax Fusion : Jurnal Nasional Indonesia

e-ISSN : 2775-4440

Vol. 1, No. 9, September 2021

\title{
KEMAMPUAN ANAK SINDROM AUTISTIK DALAM MENGARTIKULASIKAN BUNYI KONSONAN
}

\author{
Siti Fatimah
}

Poltekes BPH Cirebon

Email: Siti.fatimah06b1@gmail.com

\begin{abstract}
Abstrak
Tujuan dari penelitian ini adalah untuk mengetahui kemampuan anak dengan Sindrom Autistik (SA) dalam mengartikulasikan bunyi konsonan berdasarkan posisi pada tuturan. Penelitian dilakukan terhadap tiga anak SA. Metode penelitian yang digunakan ialah metode deskriptif kualitatif. Observasi, wawancara, dan tes artikulasi dengan flash card sebagai media digunakan sebagai cara dalam mengumpulkan data berupa kata yang dihasilkan oleh anak SA. Data yang diperoleh kemudian ditranskripsikan ke dalam transkripsi fonetis agar dapat mengetahui tingkat kemampuan artikulasi bunyi konsonan berdasarkan posisi pada tuturan. Penilaian kemampuan artikulasi dilakukan oleh tiga orang penilai yang memiliki kualifikasi di bidang lingusitik dan skala penilaian diadopsi dari Djiwandono (2008). Hasil penelitian menunjukkan bahwa meskipun ketiga anak SA memiliki usia yang hampir sama (17 dan 18 tahun), namun kemampuan artikulasi bunyi konsonan mereka berbeda-beda: informan 1 tidak mampu mengartikulasikan empat fonem seperti 2 fonem frikatif /f/ dan $/ \mathrm{v} /$, serta fonem getar / $r /$ dan fonem lateral /l/. Lalu, informan 2 tidak mampu mengujarkan lima bunyi konsonan, fonem bilabial /b/, fonem frikatif /f/, dan /s/, fonem fonem lateral $/ /$, dan fonem getar / $r /$ dengan benar. Informan 3 hanya mampu mengartikulasikan dua jenis bunyi konsonan, yaitu fonem semivokal /w/ dan 1y/. Selain itu, ketiga anak SA menujukan pola kesalahan artikulasi yang sesuai dengan teori Bauman-Waengler (2004), informan 1 melakukan pola subtitusi, omisi, dan adisi. Lalu informan 2 melakukan kesalahan pola subtitusi dan omisi, sedangkan informan 3 mengalami distorsi 15 jenis fonem /p/, /b/, /t/, /k/, /g/, /s/, /h/, /c/, /j/, /r/, /l/, /m/, /y/dan /n/.
\end{abstract}

Kata Kunci: Kemampuan Artikulasi, Anak sindrom Autistik, Pola Artikulasi

\section{Pendahuluan}

Setiap anak di dunia akan melewati proses pemerolehan bahasa, baik anak normal maupun anak berkebutuhan khusus seperti penderita sindrom autistik. Proses 
pemerolehan bahasa adalah proses yang berlangsung dalam otak seorang anak ketika memperoleh bahasa. Ada dua proses yang terjadi ketika seorang anak sedang memperoleh bahasanya, yaitu proses kompetensi dan proses performansi. Proses kompetensi adalah proses penguasaan tata bahasa yang berlangsung tanpa disadari dan merupakan syarat terjadinya proses performansi. Proses performansi terdiri dari dua proses, yaitu proses pemahaman dan penerbitan Chomsky (1957, 1965 dalam Chaer 2009:46-47). Jadi, dapat dikatakan bahwa hasil dari proses perfomansi yang melibatkan proses kompetensi merupakan kemampuan linguistik dari pemeroleh bahasa.

Dalam memperoleh bahasa, anak SA memiliki hambatan dalam mengenkode maupun mendekode bahasa. Adapun proses ini melibatkan kemampuan reseptif dan produktif anak SA. Proses reseptif dan produktif bahasa erat kaitannya dengan pemerolehan fonologi bahasa anak, yaitu proses seorang anak (normal maupun anak SA) saat mempersepsi dan memproduksi bunyi bahasa. Kemampuan memproduksi bunyi bahasa dapat dijadikan indikator kemampuan anak dalam mepersepsi atau memahami sebuah bahasa. Secara khususnya anak SA yang memiliki beranekaragam kelainan bahasa yang tidak bisa digeneralisasikan, kemampuan meproduksi bahasa mereka dapat menjadi suatu objek penelitian yang menarik dan bermanfaat.

Orang tua penyandang SA pada umumnya mulai menyadari bahwa anak mereka memiliki kelainan ketika mulai belajar berbicara. Bahkan, lebih terlihat saat anak mereka tidak dapat bicara sama sekali diusia tertentu. Indikasi seorang anak yang memiliki gangguan berkomunikasi dapat dilihat dari kata atau kalimat pertama yang dihasilkanya oleh anak (Siegel, 1996:43).

Jika anak normal mulai menghasilkan ujaran di awal tahun pertamanya, anak SA diusia yang sama belum tentu dapat mengujarkan satu atau dua kata. Hal tersebut disebabkan perkembangan bahasa anak berkebutuhan khusus bergantung pada usia mentalnya (mental age), bukan usia yang sebenarnya (cronological age) (Hurlock, 2010:86). Usia mental anak berkebutuhan khusus sangat berbeda satu dengan yang lainnya, usia mental mereka dipengaruhi oleh beberapa faktor seperti lingkungan, pola asuh, pola belajar, dan motivasi diri.

Usia sekolah adalah usia saat anak mulai memasuki dunia pendidikan baik formal maupun informal, rentang usia sekolah antara 5 sampai dengan 18 tahun. Alasan usia sekolah menjadi batasan dalam memilih subjek penelitian karena diusia sekolah seorang anak telah mampu menghasilkan berbagai bunyi, termasuk bunyi-bunyi yang cukup sulit seperti /s/, /1/, /r/ (Millestone dalam Tager-Flusberg, dkk., 2005:338). Dengan tolak ukur kemampuan produktif bahasa di usia normal anak usia sekolah.

\section{Gangguan Berbahasa Pada Anak Sd}

Loveland dan Tunali-Kotoski (2005:254-260) menyebutkan terdapat lima gangguan utama dalam berbahasa yang dialami anak SA di usia sekolah. Lima gangguan tersebut adalah echolia (mpengulangan ujaran), 75\% penderita SA pasti mengalami tahap echolia (Prizant, 1983 dalam Loveland dan Tunali-Kotoski, 2005:255)., karakteristik dalam berbicara: Anak SA atau sindrom asperger sering melakukan kesalahan dalam 
menghasilkan beberapa suara atau kesalahan artikulasi pada beberapa huruf dalam sebuah kata (Shirberg, Paul, et. Al. 2001:44), kesalahan penggunaan kata ganti orang: Anak SA sering kali mengalami kesulitan menggunakan kata ganti orang (personal pronouns) ' $\mathrm{I}$ ' dan 'you', penggunaan keduanya sering tertukar, kemampuan dalam membangun percakapan: kemampuan anak SA dalam menghasilkan atau mempertahankan percakapan tidak bisa dibandingkan dengan anak normal, dan kemampuan bercerita: Ketika anak SA berbicara memiliki kecenderungan kurang terperinci, lebih singkat, dan di dalam ceritanya terkadang ditemukan struktur kata yang salah (Bruner dan Feldman (1993) dalam Loveland dan Tunali-Kotoski, 2005:257).

Kemudian terdapat beberapa jenis kelainan berbahasa pada anak autistik yang juga diungkapkan oleh Siegel (1996: 43-59) seperti kelainan komunikasi nonverbal. Dalam kasus ini, anak autistik memiliki keterbatasan atau bahkan sama sekali tidak memiliki kemampuan dalam menggunakan ekspresi wajah, kontak mata, dan bahasa tubuh. Selain itu, terdapat pula anak SA yang menujukan gejala 'mutism' atau diam tanpa mengeluarkan suara selama beberapa tahun. Ada pula yang mengalami gejala sebaliknya yaitu hilangnya kemampuan berbahasa, gejalanya disebut dengan 'languge loss'.

\section{Metode Penelitian}

Metode yang digunakan dalam penelitian ini adalah metode deskriptif kualitatif. Fenomena anak sindrom autistik merupakan fenomena yang unik dan membutuhkan penjelasan yang terpirinci. Oleh karena itu, peneliti memilih metode deskriptif kualitatif guna menjelaskan data temuan. Hal ini juga diperkuat oleh pernyataan Alwasilah (2008) yang menyatakan bahwa dalam penelitian deskriptif, peneliti tidak hanya menyediakan pembaca dengan fakta-fakta, tetapi juga interpretasi fenomena apa yang sedang diselidiki.

Dalam penelitian ini, peneliti ingin mengetahui kemampuan anak SA dalam mengartikulasikan bunyi konsonan berdasarkan posisi pada tuturan. Sampel penelitian ini terdiri dari tiga orang anak SA. Proses pengambilan data dilakukakan melalui observasi, wawancara, dan untuk menguji daya kemampuan dalam menghasilkan ujaran anak SA, peneliti akan menguji kemampuan artikulasi secara formal melului tes pengetahuan dasar yang bersifat tematik seperti warna, hewan, sayuran, anggota tubuh, makanan, buah-buahan, alat transportasi, alat elektronik, perlengkapan sekolah, ditambah dengan tes konsep logika yang kemampuan analisa ekspresi dan emosi anak. Selain itu juga flash card digunakan sebagai alat bantu yang digunakan dalam menguji kemampuan berbahasa anak SA tersebut. Pengujian informal pun dilakukan melalui percakapan spontan antara peneliti dan para informan disela-sela pengujian formal.

Kemudian, hasil temuan tersebut dinilai oleh tiga orang penilai yang memiliki kemampuan dibidang linguistik dan menggunakan skala penilaian yang diadopsi dari Djiwandono (2008:83). Indikator yang dijadikan acuan dalam menentukan kemampuan anak SA ketika mengartikulasikan bunyi konsonan adalah menggunakan presentase kesalahan terhadap jumlah keseluruhan fonem yang dihasilkan. Adapun kriteria penilaianya kemampuan anak SA dalam mengartikulasi bunyi konsonan adalah $0 \%$ s.d $25 \%$ dinyatakan sangat mampu, $26 \%$ s.d. $50 \%$ dinyatakan mampu, $51 \%$ s.d. $75 \%$ 
dinyatakan tidak mampu, dan $76 \%$ s.d. $100 \%$ dinyatakan sangat tidak mampu mengartikulasikan bunyi konsonan.

\section{Hasil Dan Pembahasan}

Selama pengamatan pra-penelitian dan ketika penelitian, komunikasi yang dibangun di antara anak SA ialah komunikasi yang bersifat pasif. Informan jarang sekali menghasilkan ujaran tanpa ada stimulus dari orang sekitar, seperti guru atau helper. Ketika ketiga informan dibiarkan dalam satu ruangan tanpa ada orang lain tidak ditemukan komunikasi di antara mereka. Mereka hanya sibuk dengan aktifitas masingmasing. Bunyi yang dihasilkan oleh mereka bukan merupakan bunyi bahasa yang memiliki arti, hanya berupa bunyi yang tidak memiliki makna atau biasa disebut dengan 'bahasa planet' yang hanya dimengerti oleh mereka masing-masing. Kondisi serupa terjadi ketika informan dikondisikan untuk bermain di luar kelas, tidak ditemukan komunikasi di antara mereka. Mereka hanya sibuk dengan diri sendiri dan mainannya

Berdasarkan hasil penelitian selama sesi tes kemampuan artikulasi dengan menggunakan media flash card, jumlah keseluruhan data bunyi konsonan yang diujarkan anak SA selama sesi tes adalah sebanyak 700 bunyi konsonan, dengan rincian: informan 1 mengujarkan sekitar 390 bunyi konsonan, informan 2 mengucapakan 176bunyi konsonan, dan informan 3 melafalkan sejumlah 134 bunyi konsonan. Dari banyaknya bunyi konsonan yang dihasilkan oleh anak SA, tidak semua bunyi konsonan dalam bahasa Indonesia muncul, seperti bunyi konsonan /x/ dan /z/ tidak diujarkan sama sekali oleh ketiga anak SA. Berikut adalah data kemunculan bunyi konsonan yang dilafalkan oleh anak SA:

Tabel 1: Data kemunculan bunyi konsonan

\begin{tabular}{|c|c|c|c|c|c|}
\hline \multirow{2}{*}{ No. } & \multirow{2}{*}{ Fon. } & \multirow{2}{*}{ posisi } & \multicolumn{3}{|c|}{ Informan } \\
\hline & & & 1 & 2 & 3 \\
\hline \multirow{3}{*}{1} & \multirow{3}{*}{$/ \mathrm{p} /$} & $\begin{array}{l}\text { di } \\
\text { awal }\end{array}$ & 13 & 10 & 5 \\
\hline & & $\begin{array}{l}\text { di } \\
\text { tengah }\end{array}$ & 19 & 4 & 12 \\
\hline & & $\begin{array}{l}\text { di } \\
\text { akhir }\end{array}$ & 3 & 1 & 1 \\
\hline \multirow{3}{*}{2} & \multirow{3}{*}{ /b/ } & $\begin{array}{l}\text { di } \\
\text { awal }\end{array}$ & 10 & 4 & 3 \\
\hline & & $\begin{array}{l}\text { di } \\
\text { tengah }\end{array}$ & 7 & 5 & 3 \\
\hline & & $\begin{array}{l}\text { di } \\
\text { akhir }\end{array}$ & - & - & - \\
\hline 3 & $/ \mathrm{t} /$ & $\begin{array}{l}\text { di } \\
\text { awal }\end{array}$ & 9 & 4 & 3 \\
\hline
\end{tabular}

\begin{tabular}{|c|c|c|c|c|c|}
\hline \multirow{2}{*}{ No. } & \multirow{2}{*}{ Fon. } & \multirow{2}{*}{ posisi } & \multicolumn{3}{|c|}{ Informan } \\
\hline & & & 1 & 2 & 3 \\
\hline \multirow{3}{*}{11} & /c/ & $\begin{array}{l}\mathrm{di} \\
\text { awal }\end{array}$ & 5 & 3 & 2 \\
\hline & & $\begin{array}{l}\text { di } \\
\text { tengah }\end{array}$ & 4 & 1 & 2 \\
\hline & & $\begin{array}{l}\text { di } \\
\text { akhir }\end{array}$ & - & - & - \\
\hline \multirow{3}{*}{12} & $/ \mathrm{j} /$ & $\begin{array}{l}\text { di } \\
\text { awal }\end{array}$ & 2 & 3 & 1 \\
\hline & & $\begin{array}{l}\text { di } \\
\text { tengah }\end{array}$ & 2 & 3 & 2 \\
\hline & & $\begin{array}{l}\text { di } \\
\text { akhir }\end{array}$ & - & & - \\
\hline 13 & $/ \mathrm{m} /$ & $\begin{array}{l}\mathrm{di} \\
\text { awal }\end{array}$ & 17 & 8 & 5 \\
\hline
\end{tabular}




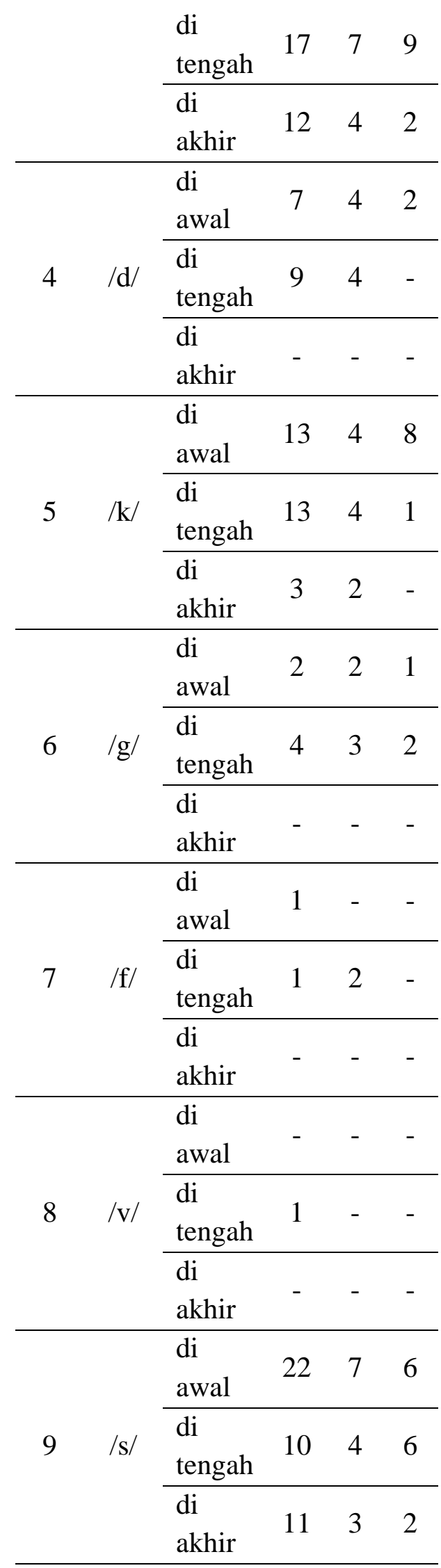

\begin{tabular}{|c|c|c|c|c|c|}
\hline & & $\begin{array}{l}\text { di } \\
\text { tengah }\end{array}$ & 15 & 8 & 6 \\
\hline & & $\begin{array}{l}\text { di } \\
\text { akhir }\end{array}$ & 4 & 2 & - \\
\hline \multirow{3}{*}{14} & $/ \mathrm{n} /$ & $\begin{array}{l}\text { di } \\
\text { awal }\end{array}$ & 4 & - & 1 \\
\hline & & $\begin{array}{l}\text { di } \\
\text { tengah }\end{array}$ & 18 & 13 & 4 \\
\hline & & $\begin{array}{l}\text { di } \\
\text { akhir }\end{array}$ & 14 & 3 & 1 \\
\hline \multirow{3}{*}{15} & $/ \check{\mathrm{n}} /$ & $\begin{array}{l}\text { di } \\
\text { awal }\end{array}$ & - & - & - \\
\hline & & $\begin{array}{l}\text { di } \\
\text { tengah }\end{array}$ & 1 & 1 & - \\
\hline & & $\begin{array}{l}\text { di } \\
\text { akhir }\end{array}$ & - & - & - \\
\hline \multirow{3}{*}{16} & $/ \mathrm{y} /$ & $\begin{array}{l}\text { di } \\
\text { awal }\end{array}$ & - & - & - \\
\hline & & $\begin{array}{l}\text { di } \\
\text { tengah }\end{array}$ & 4 & - & - \\
\hline & & $\begin{array}{l}\text { di } \\
\text { akhir }\end{array}$ & 15 & 7 & 6 \\
\hline \multirow{3}{*}{17} & $/ 1 /$ & $\begin{array}{l}\text { di } \\
\text { awal }\end{array}$ & 5 & 2 & 3 \\
\hline & & $\begin{array}{l}\text { di } \\
\text { tengah }\end{array}$ & 4 & 8 & 4 \\
\hline & & $\begin{array}{l}\text { di } \\
\text { akhir }\end{array}$ & 6 & 3 & 5 \\
\hline \multirow{3}{*}{18} & $/ \mathrm{r} /$ & $\begin{array}{l}\text { di } \\
\text { awal }\end{array}$ & 6 & 3 & 2 \\
\hline & & $\begin{array}{l}\mathrm{di} \\
\text { tengah }\end{array}$ & 18 & 10 & 6 \\
\hline & & $\begin{array}{l}\text { di } \\
\text { akhir }\end{array}$ & 8 & 5 & 6 \\
\hline \multirow{3}{*}{19} & $/ \mathrm{w} /$ & $\begin{array}{l}\text { di } \\
\text { awal }\end{array}$ & 1 & - & - \\
\hline & & $\begin{array}{l}\text { di } \\
\text { tengah }\end{array}$ & 1 & 1 & 1 \\
\hline & & $\begin{array}{l}\text { di } \\
\text { akhir }\end{array}$ & - & - & - \\
\hline
\end{tabular}




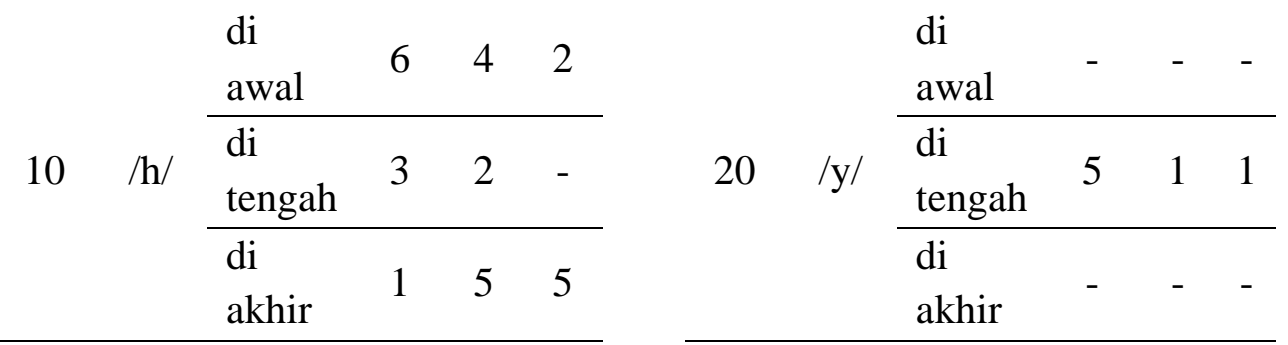

Meskipun menggunakan media yang sama, kemunculan bunyi konsonan setiap anak SA berbeda-beda. Hal tesebut dipengaruhi oleh kemampuan setiap anak SA dalam menghasilkan tuturan dan juga kemampuan mereka dalam mempertahankan percakapan dengan peneliti. Semakin banyak tuturan yang dihasilkan semakin banyak pula bunyi konsonan yang dihasilkanya dan semakin tinggi pula kemampuanya dalam mengartikulasikan bunyi konsonan. Selain itu, faktor lainnya yang menyebabkan perbedaan kemunculan bunyi konsonan diantara informan adalah perbedaan perkembangan bahasa ketiga anak SA. Informan 1 merupakan anak SA yang termasuk pada kategori HFA atau anak SA dengan kemampuan berbahasa cukup tinggi bila dibandingkan dengan anak SA lainnya. Hal tersebut dibuktikan dengan kemampuanya dalam merepon setiap pertanyaan peniliti, apabila kecepatan informan 1 dalam merespon di rata-rata maka kecepatnya adalah 0,5 sampai dengan 1 detik setiap pertanyaanya. Kemampuan merespon dengan kecerdasan linguistik anak SA.

Informan 2 masih dalam proses pemerolehan bahasa, hal tersebut ditandai dengan kemamampuan berbahasa informan 2 yang masih pada tahap echolia atau tahapan mengulang-ulang kata yang didengar olehnya (lihat Loveland dan Tunali-Kotoski, 2005:256). Kondisi berbahasa informan 3 sama dengan balita berusia 12 hingga 24 bulan yang hanya mampu memproduksi bunyi vokal dengan baik dan hanya beberapa bunyi konsonan saja. Oleh karena itu, dalam berkomunikasi dengan lingkungannya informan 3 hanya mengandalkan kemampuan berbahasa non-verbalnya saja.

Kemampuan anak SA dalam mengartikulasikan bunyi kosonan berdasarkan posisi tuturan, dinilai berdasarkan frekuensi kesalahan artikulasi dan dibagi dengan banyaknya kemunculan bunyi konsonan. Berikut adalah contoh analisis dari bunyi konsonan subkelompok stop. Angka berupa \% dalam tabel 2 menunjukkan presentase kemampuan setiap anak SA. Besarnya angka presentase menunjukkan ketidakmampuan anak SA, sedangkan semakin kecil angka presentase membuktikan bahwa anak SA mampu mengartikulasikan bunyi konsonan dengan benar. Fonem sub-kelompok stop ([p], [b], $[\mathrm{t}]$, $[\mathrm{d}],[\mathrm{k}]$, dan $[\mathrm{g}]$ ) memiliki ciri penutupan secara penuh alat artikulasi oral guna mencegah aliran udara keluar melalui rongga mulut. Bunyi konsonan stop bisa dikenal juga dengan sebutan plosif. Selain itu fonem stop juga termasuk dalam fonem yang bersuara (+voice) dan tidak bersuara (-voice) bila dilihat dari bergetar atau tidaknya pita suara (lihat Davenport dan Hannahs, 2005:19). 
Tabel 2. Kemampuan artikulasi bunyi konsonan anak SA sub-kelompok stop

\begin{tabular}{|c|c|c|c|c|c|c|c|c|c|c|c|}
\hline \multirow{4}{*}{$\begin{array}{l}\mathrm{N} \\
\mathrm{O}\end{array}$} & \multirow{4}{*}{$\begin{array}{c}\text { Fone } \\
\mathrm{m}\end{array}$} & \multirow{3}{*}{$\begin{array}{l}\text { Posisi } \\
\text { pada }\end{array}$} & \multicolumn{3}{|c|}{ Informan 1} & \multicolumn{3}{|c|}{ Informan 2} & \multicolumn{3}{|c|}{ Informan 3} \\
\hline & & & $\sum$ & $\sum$ & & $\sum$ & $\sum$ & & $\sum$ & $\sum$ & \\
\hline & & & Dat & Erro & $\%$ & Dat & Erro & $\%$ & Dat & Erro & $\%$ \\
\hline & & tuturan & $\mathrm{a}$ & $\mathrm{r}$ & & $\mathrm{a}$ & $\mathrm{r}$ & & $\mathrm{a}$ & $\mathrm{r}$ & \\
\hline \multirow{4}{*}{1} & \multirow{4}{*}{$/ \mathrm{p} /$} & diawal & 13 & 1 & $8 \%$ & 10 & 2 & $\begin{array}{l}20 \\
\%\end{array}$ & 5 & 4 & $80 \%$ \\
\hline & & ditenga & & & 11 & & & 25 & & & \\
\hline & & $\mathrm{h}$ & 19 & 2 & $\%$ & 4 & 1 & $\%$ & 12 & 6 & $50 \%$ \\
\hline & & diakhir & 3 & 0 & $0 \%$ & 1 & 0 & $0 \%$ & 1 & 0 & $0 \%$ \\
\hline \multirow{2}{*}{2} & \multirow{2}{*}{$/ \mathrm{b} /$} & diawal & 9 & 0 & $0 \%$ & 4 & 2 & $\begin{array}{l}50 \\
\%\end{array}$ & 3 & 2 & $67 \%$ \\
\hline & & $\begin{array}{c}\text { ditenga } \\
\mathrm{h}\end{array}$ & 7 & 0 & $0 \%$ & 5 & 1 & $\begin{array}{l}20 \\
\%\end{array}$ & 3 & 1 & $33 \%$ \\
\hline \multirow{3}{*}{3} & \multirow{3}{*}{$/ \mathrm{t} /$} & diawal & 9 & 1 & $\begin{array}{l}11 \\
\%\end{array}$ & 4 & 0 & $0 \%$ & 3 & 3 & $\begin{array}{c}100 \\
\%\end{array}$ \\
\hline & & $\begin{array}{c}\text { ditenga } \\
\mathrm{h}\end{array}$ & 17 & 1 & $6 \%$ & 7 & 0 & $0 \%$ & 9 & 5 & $56 \%$ \\
\hline & & diakhir & 12 & 0 & $0 \%$ & 4 & 0 & $0 \%$ & 2 & 2 & $\begin{array}{c}100 \\
\%\end{array}$ \\
\hline \multirow{2}{*}{4} & \multirow{2}{*}{$/ \mathrm{d} /$} & diawal & 7 & 0 & $0 \%$ & 4 & 1 & $\begin{array}{l}25 \\
\%\end{array}$ & 3 & 2 & $67 \%$ \\
\hline & & $\begin{array}{c}\text { ditenga } \\
\mathrm{h}\end{array}$ & 9 & 0 & $0 \%$ & 4 & 0 & $0 \%$ & 0 & 0 & 0 \\
\hline \multirow{3}{*}{5} & \multirow{3}{*}{$/ \mathrm{k} /$} & diawal & 13 & 1 & $8 \%$ & 4 & 1 & $\begin{array}{l}25 \\
\%\end{array}$ & 8 & 7 & $88 \%$ \\
\hline & & $\begin{array}{c}\text { ditenga } \\
\mathrm{h}\end{array}$ & 13 & 0 & $0 \%$ & 4 & 0 & $0 \%$ & 1 & 1 & $\begin{array}{c}100 \\
\%\end{array}$ \\
\hline & & diakhir & 3 & 0 & $0 \%$ & 2 & 1 & $\begin{array}{l}50 \\
\%\end{array}$ & 0 & 0 & \\
\hline \multirow[b]{2}{*}{6} & \multirow[b]{2}{*}{$/ g /$} & diawal & 2 & 0 & $0 \%$ & 2 & 0 & $0 \%$ & 1 & 0 & $0 \%$ \\
\hline & & $\begin{array}{c}\text { ditenga } \\
\mathrm{h}\end{array}$ & 4 & 0 & $0 \%$ & 3 & 0 & $0 \%$ & 2 & 0 & $0 \%$ \\
\hline
\end{tabular}

keterangan: warna gelap menunjukkan informan tidak menghasilkan ujaran yang mengandung bunyi konsonan terkait.

Pada tabel 2. dapat dilihat bahwa informan 1 dan 2 tidak terlalu mengalami kesulitan (sangat mampu) dalam mengartikulasikan fonem /p/ bila dibandingkan dengan informan 3 yang masih tidak mampu mengujarkan fonem /p/. Informan 1 mengalami kesulitan mengartikulasikan fonem /p/ di awal tuturan hanya pada satu tuturan dari 13 tuturan yang mengandung fonem /p/. Dia melakukan kesalahan artikulasi pada tuturan 
<pink> yang seharusnya dilafalkan [pi:nk] menjadi [bi:yk]. Dalam kasus ini informan 1 mengganti (subtitusi) fonem /p/ menjadi fonem /b/, kondisi serupa juga terjadi pada informan 1 ketika $/ \mathrm{p} /$ berada diposisi tengah tuturan <opung>. Tuturan tersebut seharusnya dilafalkan [opuy] yang kemudian menjadi [obuy]. Fonem /p/ dan /b/ keduanya termasuk dalam kelompok konsonan bilabial plosif yang cara pelafalanya hampir serupa. Menutup bibir atas dan bawah, kemudian terdapat sedikit letupan udara membuka kedua bagian bibir. Kesalahan lainnya adalah terdapat penghilangan (omisi) bunyi konsonan /p/ dengan posisi di tengah pada tuturan <leptop>, dilafalkan [ye:top] yang seharusnya [leptop].

Serupa dengan informan 1, informan 2 tidak mengalami banyak kesulitan dalam mengucapkan bunyi konsonan /p/. Dia pun hanya melakukan 3 kesalahan total jumlah kemunculan sejumlah 15 kali. Kesalahan artikulasi yang dilakukan oleh informan 2 adalah penghilangan fonem /p/. Dua kali penghilangan fonem /p/ terjadi di posisi awal tuturan dan satu kali di tengah tuturan. Tuturan tersebut adalah <pernah>, 〈padang $\rangle$, dan $<$ leptop>. Ketiga tuturan tersebut seharusnya dilafalkan [pərnah], [paday], dan [leptop], namun dilafalkan menjadi [ərnah], [da:], dan [to:p].

Data kemampuan anak SA dalam mengartikulasikan bunyi kosonan selengkapnya dapat dilihat pada gambar 1 .

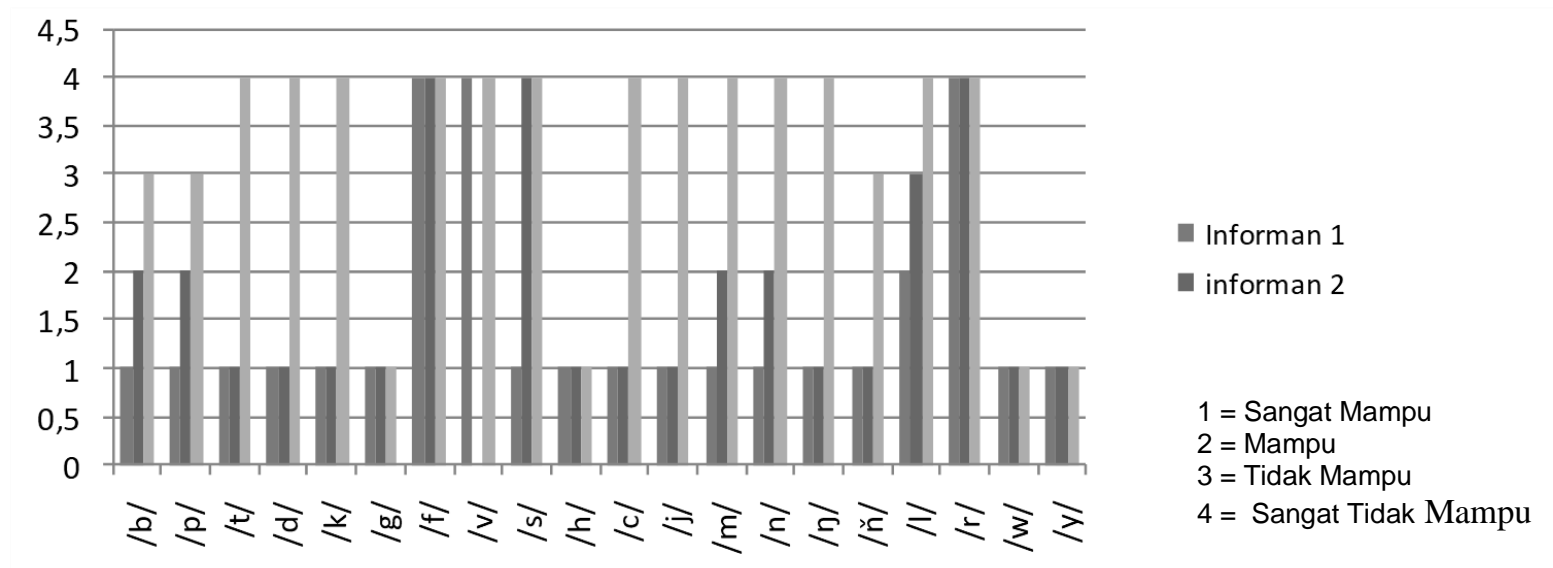

Gambar 1: Grafik kemampuan anak SA dalam mengaartikulasikan bunyi konsonan

Berdasarkan gambar 1 dapat dilihat bahwa kemampuan informan 1 lebih baik bila dibandingkan dengan informan 2 dan 3, sedangkan informan 3 memiliki kemampuan yang paling rendah dalam mengujarkan konsonan dibandingkan yang lainnya. Dari 20 bunyi konsonan yang diujarkan oleh informan 1 hanya 16 bunyi konsonan yang dapat diujarkan dengan benar, yaitu bunyi konsonan /p/, /b/, /m/, /w/, /t/, /d/, /s/, /n/, /k/, /g/, /c/, $/ \mathrm{j} /, / \mathrm{n} /, / \mathrm{y} /, / \mathrm{h} /$, dan $/ \mathrm{y} /$. Ada empat bunyi konsonan yang tidak dapat diujarkanya dengan benar, yaitu bunyi konsonan /f/ di awal dan di tengah tuturan, bunyi konsonan /v/ di 
tengah tuturan, bunyi konsonan /r/ di posisi awal, tengah dan akhir tuturan, dan bunyi konsonan /l/ di awal tuturan.

Kemudian informan 2 hanya mampu mengujarkan 14 bunyi konsonan dengan baik, yaitu bunyi konsonan /p/,/m/, /w/, /t/, /d/, /n/, /g/, /c/, /j/, / Һ̌/, /y/, /h/, / y/ dan informan 2 tidak mampu mengujarkan enam bunyi konsonan (/b/, /f/, /s/, /l/, dan /r/) dengan benar. Informan 2 tidak mampu mengujarkan bunyi konsonan /b/ pada posisi, bunyi konsonan /k/ di akhir tuturan, bunyi konsonan /f/ di awal tuturan, bunyi kosonan /s/ di semua posisi (awal, tengah, dan akhir) tuturan, bunyi konsonan /l/ di awal dan tengah tuturan, dan bunyi konsonan /r/ di semua posisi (awal, tengah, dan akhir) tuturan. Informan 3 hanya mampu mengartikulasikan dua bunyi konsonan yaitu hanya bunyi semivokal saja (/w/ dan /y/).

\section{Kesimpulan}

Hasil penelitian menunjukkan bahwa meskipun ketiga anak SA memiliki usia yang hampir sama (17 dan 18 tahun), namun kemampuan artikulasi bunyi konsonan mereka berbeda-beda: informan 1 tidak mampu mengartikulasikan empat fonem seperti 2 fonem frikatif /f/ dan /v/, serta fonem getar /r/ dan fonem lateral /l/. Lalu, informan 2 tidak mampu mengujarkan lima bunyi konsonan, fonem bilabial /b/, fonem frikatif /f/, dan /s/, fonem fonem lateral /1/, dan fonem getar /r/ dengan benar. Informan 3 hanya mampu mengartikulasikan dua jenis bunyi konsonan, yaitu fonem semivokal /w/ dan /y/. Selain itu, ketiga anak SA menujukan pola kesalahan artikulasi yang sesuai dengan teori Bauman-Waengler (2004), informan 1 melakukan pola subtitusi, omisi, dan adisi. Lalu informan 2 melakukan kesalahan pola subtitusi dan omisi, sedangkan informan 3 mengalami distorsi 15 jenis fonem /p/, /b/, /t/, /k/, /g/, /s/, /h/, /c/, /j/,/r/, /l/, /m/, /y/ dan $/ \mathrm{n} /$. 
Siti Fatimah

\section{Bibliografi}

Alwasilah, A. C. (2008). Pokoknya kualtitatif. Jakarta: PT. Dunia Pustaka Jaya.

Chaer, A. (2009). Psikolinguistik. Jakarta: Rineka Cipta.

Bauman-Waengler, J. (2004). Articulatory and phonological impairment: a clinical focus (2nd ed.).Boston: Pearson.

Davenport, M. dan Hannahs, S. J. (2005). Introducing Phonetics and Phonology. London: Oxford University Press Inc.

Djiwandono, S. (2008). Tes bahasa. Jakarta: PT. Indeks.

Hurlock. E. B. (2010). Psikologi perkembangan. Jakarta: Erlangga.

Loveland, K. dan Tunali-Kotoski. (2005) The school age with an autistic spectrum disorder. [ed.3] Handbook of Autism and Pervasive Development Disorders. Hlm. 247-287, New Jersey: John Wiley \& Sons, Inc.

Siegel, B. (1996). The World of the Autistic Child. New York: Oxford University Press.

Tager-Flushberg, dkk. (2005). 'Language and communication in autism'. Dalam Volkmar, F.

Dan Klin, A. (2005). 'Issues in the classification of autism and related condition. [ed.3] Handbook of Autism and Pervasive Development Disorders. Hlm. 6-41, New Jersey: John Wiley \& Sons, Inc. 